\title{
When Faculty Use Instructional Technologies: Using Clark's Delivery Model to Understand Gender Differences
}

\section{KATY CAMPBELL \& STANLEY VARNHAGEN}

University of Alberta

\section{ABSTR'ACT}

Instructional and learning technologies are playing an increasingly important role in postsecondary education, but there is evidence that a number of differences exist in how females and males approach, perceive, and implement these technologies. As faculty start to offer more of their courses using flexible delivery methods such as Web-based conferencing, it is important to understand what gender differences may exist in faculty members' approaches to instructional and communications technologies so that this process may be better facilitated. This paper has three purposes: to highlight some of the major gender-related differences noted in the literature, including some from a feminist perspective; to present and discuss related findings found in an exploratory, post-hoc analysis of survey data collected from our institution; and finally, to suggest areas for future research. Richard Clark's (1994) model distinguishing between Instructional and Delivery Technologies provides a framework for this discussion. 


\section{RÉSUMÉ}

Les technologies d'instruction et d'apprentissage occupent un rôle de plus en plus important dans le domaine de l'enseignement post secondaire. Toutefois, certaines données suggèrent qu'il existe des différences dans la manière dont les femmes et les hommes abordent, percoivent et utilisent ces technologies. Dans la mesure où le corps professoral offre de plus en plus de cours avec des méthodes flexibles, telles que les discussions en ligne, il est important de comprendre quelles sont les différences entre les sexes dans la manière dont les professeures et professeurs abordent les technologies d'instruction et de communication, dans le but de mieux faciliter ce processus. Cet article a trois objectifs : (1) de souligner quelques-unes des plus importantes différences entre les sexes rapportées dans la littérature, incluant certaines provenant d'une perspective feministe; (2) de présenter et discuter certains résultats connexes provenant d'une analyse exploratoire a posteriori, réalisée à partir de données recueillies dans notre institution; et (3) de suggérer quelques orientations pour des recherches futures. Le modèle de Richard Clark (1994), qui fait la distinction entre les technologies d'instruction et de diffusion, fournit un cadre de reférence pour cette discussion.reférence pour cette discussion.

Instructional and learning technologies are playing an increasingly important role in tertiary education, but there is evidence that differences exist in how many females and males perceive and use these technologies. This paper has three purposes: to provide a brief literature review of some of the gender differences related to experiences with, and attitudes towards, teaching and learning technologies; to present and discuss suggestive findings from an exploratory, post-hoc analysis of survey data collected from our institution; and to suggest a theoretical framework for interpretation and further research.

Since 1996 the University of Alberta's Academic Technologies for Learning Unit has surveyed academic staff three times regarding their use of information and communications technologies. The first two surveys (1996 and 1997-98 respectively) focused on the use of learning technologies in 
teaching and learning, while the third survey (1999-2000, available at http://www.atl.ualberta.ca/services/evaluation/TLSTitle.htm), was broaderbased and focused on issues of teaching and learning rather than exclusively on the use of information and learning technologies.

In the second Faculty survey (1997) a number of interesting trends emerged in the way male and female faculty viewed technology in relation to teaching, research, student support, and collegial contacts. The survey data are available online. ${ }^{1}$ This paper describes the first stage of a longer-term research study concerned with the experiences of female faculty with information and educational technologies, is confined to a discussion of only the empirical results of the Faculty Survey on Instructional Technology (1997-98), and the analysis is therefore both descriptive and gendered in nature. The differences among faculty members that were revealed in the responses to a 5-point Likert-style questionnaire encouraged (the first author) to pursue an action research project involving over 50 faculty interviews and focus groups. Focusing exclusively on female faculty's stories of practice, neither the long-term study nor this analysis is intended to be comparative. The data continues to contribute to our understanding of, and programming for, the needs of all faculty at our institution. In that gender differences do exist, understanding and facilitating the potentially unique related needs of faculty will assist us in appropriate faculty development.

This paper is comprised of four main parts: The first part suggests a theoretical framework for understanding the different ways in which faculty may consider implementing technology for teaching and learning. The second part is a discussion of general issues facing female faculty in academe. This review, from both feminist and policy research in higher education, is intended to provide a context for interpretation of the ways in which female faculty describe their encounters with technology. In the third part we provide a brief historical overview of the research literature related to technology as a social construction, that is, how women may have been encouraged (or discouraged) to use technologies by socio-cultural and political factors. Finally, we relate the findings from the Faculty Survey to the work on women's encounters with technologies and potentially to their learning and teaching styles. Further research initiatives are described briefly. 


\section{INSTRUCTIONAL AND DELIVERY TECHNOLOGIES}

Educational technologies have been used in postsecondary environments since at least the early $60 \mathrm{~s}$ and the advent of teaching machines (Gillespie, 1998). However, these technologies have existed uneasily within tertiary institutions and have often been associated only with technologically sophisticated faculty. These "early adopters" have sometimes been viewed with suspicion by their colleagues (Anderson, Varnhagen, \& Campbell, 1998; Rogers, 1995a). To date much of the research undertaken to support the use of instructional technologies has historically been inconclusive (Russell, 1997).

Clark (1994) has reconceptualized instructional technologies in a way that is more helpful in providing insight into their effects on learners. Clark suggests a framework for examining instructional technology by distinguishing two components - delivery technology, and instructional technology. Clark defines delivery technology (e.g., hardware and software) as the technology used to distribute the instruction to the student, while instructional technology (e.g., pedagogy) comprises the underlying instructional methods that are used. The delivery technology is often the focus with new technologies but the instructional technology may be the more important factor in learning. When new instructional technologies are used, however, not only the delivery methods, but often the instructional methods will be different from conventional instruction. Clark (1994) contends that a reason many technology studies do not show differences is because only the delivery technology is varied, while the instructional technology remains the same, so the effect on the students may be minor. Clark further contends that for significant findings to occur the instructional methods need to be different. That is, to look at the delivery technology alone, as is often done, is overly simple.

Utilising new instructional technologies involves changes to both delivery methods and instructional methods, therefore understanding their relative roles is important. This distinction between delivery technologies and instructional methods can provide a valuable framework for the examination of gender-related differences among postsecondary instructors. An individual focusing initially on the instructional methods 
may be more likely to choose a consistent delivery technology. However, an individual focusing initially on the delivery technology may not recognise the corresponding changes in instructional technology, or the impact of the method. For example, a faculty member who decides to use a tool such as WebCT"T , without first determining "why" and "how" it will be used, has chosen the delivery technology first. A faculty member who first decides to encourage student interaction, and then chooses a Web-based conferencing tool to facilitate discussion, has chosen the instructional technology first, then the delivery technology.

Suchman and Jordan (1988, in Balka \& Doucette, 1994) made another distinction in pointing out that both the design and use of technology involve appropriation: most technologies and software are designed apart from their end users, causing an inevitable gap between scenarios of design and circumstances of use. In other words, often neither instructors nor learners participate in learning design decisions; they are merely consumers. "Off-the-shelf" instructional CD-ROMS are an example of this. In these cases, the underlying instructional methods may not be evident. This situation may be changing, however, as design tools and platforms, like WebCT, become more accessible and user-friendly and instructors can more easily create their own learning environments.

We hypothesize that female faculty may be more inclined to focus on the instructional methodology (such as class discussion), than the specific delivery technology (for example, a computer discussion list). The delivery technology will be chosen because it facilitates the discussion.

Gender issues related to technology have been observed and reported quite consistently over several decades. Most of this research examines female experiences learning with computers during their public schooling years and throughout their undergraduate years. Spotts, Bowman and Mertz (1997) have observed that while most studies have investigated "possible gender differences in education, computer use, attitudes towards computers, math and sciences...only a few have addressed potential gender differences related to faculty use of and attitudes toward instructional technology in higher education" (p. 425). Like these authors, we wondered if female faculty, who as learners may have been affected by consistently reported gender-related barriers, have been 
socialized to technology in ways that might have an impact today on their instructional decisions related to educational technologies. For example, past research has shown that:

- Males have traditionally had better access to technology (Balka \& Doucette, 1994; Gilbert \& Kile, 1996).

- Achievement and motivation have been related to access to technology in both formal and informal learning contexts (Krendl \& Broihier, 1992; Liao, 1999; Pryor, 1995; Spenneman, 1998; Taylor \& Mounfield, 1994).

- When confronted with instructional technology female selfefficacy, which is related to achievement and motivation, has been lower than that of males (Ayerson \& Reed, 1995-96; Burge, 1994; Taylor, 1997).

- Delivery technology has often been presented in "gendered" terms that tend to be male oriented, for example arcade-type interfaces, use non-gender neutral metaphors, and militaristic language such as "killing a job" (Burge, 1994; Inkpen, 1997; Spender, 1995; Wylie, 1995).

At the same time, research related to gender-related roles in postsecondary institutions reveals that (Park, 1996; Ramsden \& Martin, 1996):

- Men have been proportionately better represented at the higher levels of academia, and women at the lower ranks.

- Women have been more likely to rate teaching and learning higher in importance than their male colleagues

This raises a number of interesting questions:

1. Will women have different reasons for using technology in teaching then men, and if so, why?

2. Is it more risky or stressful for women to use technology than men, given both their differences in academic status, and the social history of technology implementation?

3. Are different strategies indicated to support female and male faculty in the use of learning technologies? 
Another way to examine this complex picture is to break technology use into finer components. Some of the emerging questions that can be examined by gender include:

- How and why is the technology used?

- Which instructional/information technologies (IT) are preferred?

- How does the IT background of the faculty affect its use?

In presenting the data from the University of Alberta's Faculty Survey (1997-98) we attempt to synthesize some of these theoretical dimensions and questions by arguing that some of the differences revealed in the ways female and male faculty adopt technologies are embedded in the ways in which women experience, understand, and enact instructional and collegial relationships.

\section{WOMEN IN ACADEMIA: GENDER-RELATED DIFFERENCES}

\section{Differences in Academic Roles}

Women have tended to develop their pedagogical values and approaches in an institutional context that has remained stubbornly inequitable since their significant entry into academe after the First World War (Dagg, 1998). They are significantly under-represented, especially at the level of full-time professor (Cumming-Speirs, Amsel, Baines, \& Pickel, 1998; Hagedorn, 1996; Park, 1996; Quazi, 1996; Wenneras \& Wold, 2000), and have historically spent a disproportionately higher percentage of their time on activities related to teaching and student advisement than on research activities (Stecklein \& Lorenz, 1986; Park, 1996; Quazi, 1996; Ramsden \& Martin, 1996).

Based on the work of these researchers and others (Valian, 1999) a composite of the female faculty member is suggested. Compared to her male colleagues, she is less likely to occupy a tenured or tenure-track position, at the higher ranks she is often older; her teaching load is likely heavier; and she is less likely to have an authoritative or administrative role in the institution (Hamrick, 1998; Park, 1996; Ramsden \& Martin, 1996). She is likely to place high value on interactions with students (Lacey, Saleh, \& Gorman, 1998; Robin \& Harris, 1998); appears to be more 
learner-centered in her beliefs and teaching styles, being less inclined to use didactic techniques as her primary instructional method (Singer, 1996); tends to spend more time preparing to teach; and uses a greater range of evaluation techniques (Kulis, 1997). Since activities that are teaching, rather than research related, might be less valued by the institution for promotion and tenure decisions, women may get less credit for their time than more research-oriented male counterparts (Verrier, 1994).

\section{Risk Factors}

Innovative instruction, including technology-based instruction, carries added risk when compared to more conventional instruction, including unanticipated delivery problems. It is not unusual for student course evaluations to be lower than for conventional instruction (Hara \& Kling, 2000; Morrison, 1997). These evaluations are often used by Faculty Evaluation Committees to help determine faculty pay raises and tenure. Given a higher relative proportion who do not have tenure, women faculty may be proportionately more vulnerable to risk factors (Gates, 2000 ), or may consider themselves to be more at risk.

\section{Female Instructional Perspective}

Citing studies of feminist pedagogy from the late 1980s (Aisenberg \& Harrington, 1988; Weiler, 1988), Middleton (1993) claims that "Empirical research supports the claim that women teachers - to a greater degree than men teachers - prefer the pedagogies that are based on students' personal knowledge" (p. 114). More recent empirical studies (Elijah, 1996; Lacey, Saleh, \& Gorman, 1998; Robin \& Harris, 1998) suggest that female faculty tend to embed curricular and instructional decisions in their students' personal experiences and understandings, as well as their own. Female faculty may be less concerned with control and more inclined to prefer teaching-learning decisions constructed by learners (Lacey, Saleh, \& Gorman, 1998). These writers describe the contexts in which women faculty may prefer to study and teach as inclusive and embodied in relation to moral patterns of nurturance and care (Elliott \& Woloshyn, 1997; Ramsden \& Martin, 1996). In addition to these gender-based styles and beliefs, Park (1996) describes preferred 
learner-centered approaches such as class discussion, cooperative learning, experiential learning, fieldwork, group projects, student-developed activities, and peer assessment.

The literature on critical feminist teaching in academia also provides a framework for our interpretations of the trends identified by respondents to the Faculty Survey (Kimme1, 1999; Tisdell, 2000; Weiler, 1998). Academic tradition and structures have tended to view men as producers of knowledge (the researchers) where women are seen as conduits (the teachers). One could argue that women do produce knowledge, but that they may share it in different ways, seeking one-to-one communication and networks of invited participation. Based on this, we hypothesize that, given a choice of learning methods and technologies, those that support increased interaction and participatory networks are more likely to appeal to female faculty.

Women's relationships with technology have not been entirely comfortable. The next section outlines the difficulties women have historically encountered in their relations with technology.

\section{WOMEN AND INSTRUCTIONAL TECHNOLOGIES: AN OVERVIEW}

Western thought, as represented in the academic tradition of the classroom lecturer, posits one truth to be discovered, and learning as an objective logical activity of approaching and receiving that truth through the expert; the one source of intellectual authority (Magolda, 1992). Traditional learning technology designs, represented by much of the highly structured computer-based training packages that have been produced since the early 1980's, reflect a dualistic, abstract, and systematic approach to learning (Ewing, Dowling, \& Coutts, 1998). Many social critics have criticized androcentric designs that are opposed to the ways in which women are socialized to process information (Ayerson \& Reed, 1995-96; Ganguly, 1992; Shade, 1993; Winkelman, 1997). That is, women have been taught, and may prefer, to process information using cognitive and affective styles that are more relational and associative in nature (Turkle, 1995). 
This criticism of traditional learning design, in relation to adult women learners, has been described in the work of MacKeracher (1996), Magolda (1992), and others (Kimmel, 1999). This body of work suggests that knowledge may be socially constructed though different worldviews, and shared and elaborated through relationship, conversation and social negotiation. In this paper we take the view that technology can support these values, and may appeal to female faculty for this reason. ${ }^{2}$ However, while some instructional methods and delivery technologies may be well suited to female strategies, women's comfort and history with delivery technology, at least in the Western world, may cause hesitation in the use of instructional technology. Elements of exclusion include: attitude, anxiety and motivation; access; socialization and culture; learning context; learning design; nature of content; and learning and cognitive style differences. Given this context, it is possible that the choices women make to use technologies (or not) would reflect this history.

Technology is neither neutral, nor a-political in design and implementation (Clegg, Mayfield, \& Trayhurn, 1999). Therefore, as a team working with faculty to develop and evaluate distributed learning contexts, we are concerned that instructional technology be a thoughtful choice in a learning environment that is inclusive and accessible for both learners and instructors. On postsecondary campuses we have been somewhat guilty of de-contextualizng technology; not seeing it as reflecting a set of values that may privilege certain individuals over others (Nawratil, 1999). For example, working in a campus computer lab on self-directed materials such as self-paced tutorials may not be comfortable for the relational learner. If this is the case for learners it may also be the case for faculty who, because of their preferred teaching style and/or their socialization to technology, may not choose either an instructional technology or a delivery technology that encourages autonomous learning. Since these environments are ubiquitous on postsecondary campuses we need to be thoughtful about models of faculty support to assist faculty to either adapt these environments to their own teaching styles and values, or to develop instructional technologies that do not rely on them. This is a possible area of future research. 


\section{Is Technology Gendered?}

According to many researchers, technology has traditionally played a gendered role in Western society (Bromley, 1998; Cockburn \& Ormond, 1993; Spender, 1995). A persistent concern expressed by female researchers is that since men have, until very recently, been the main creators and designers of delivery technology such as software, an androcentric cultural model has often been extended into the learning environment. In that women's relationships to technology may be socially constructed, design and implementation decisions will be embedded in cultural practices (Suchman \& Jordan, 1988). That is, there is no inherently negative relationship between women and computers, only a socially constructed one that historically underlines anxiety and resistance. It may be possible that many of those who develop technologies are most drawn to the delivery technology and may either be unaware of the accompanying instructional methodology or have only a secondary interest in this component. Viewing technology in this way, as a social construction suggests the politics of technology could continue to disenfranchise individuals on the basis of race, class, sexual orientation, and disability, as well as gender (Bryson \& de Castell, 1998).

An emphasis on delivery technology alone may exclude groups of learners, for example, adult women learning at a distance and their female teachers who must use technology to deliver instruction and support learning (Burge, 1994). That is, focusing on technological infrastructure before the faculty development process essential to its effective use underlines our concern that faculty may be required to interact with technology reflecting learning designs and environments that emphasize autonomous, rational, abstract approaches. In our institution, for example, so-called "Smart Classrooms" were initially designed and installed without consultation with teaching faculty. While these problems affect both sexes, comments from women in particular included complaints about the emphasis on display technologies; fixed lecterns with control panels that were too high for many female faculty and created a physical barrier between the teacher and the students (since it was difficult to stand in front of the lectern and still control the technologies); inadequate lighting except for a reading light attached to the lectern; inflexible 
room arrangements; and large size, which resulted in their exclusive use for large classes. Taken together, these factors made it difficult to use an instructional methodology other than a didactic, instructor-controlled approach. This example reflects institutional planning for delivery, rather than instructional technology.

\section{Barriers to Female Participation}

Factors that have been identified as barriers to full control of, and participation in, technological environments can be related to personal, political, and sociological factors. These factors influence not only the development of skill levels and self-efficacy in the use of technologies, but also the value frameworks through which females evaluate technologies for teaching and learning. Taken as barriers, these factors are problematic in postsecondary contexts as educational pressure mounts to create more learning experiences supported by technology.

Personal factors. Personal barriers in the use of learning technologies include attitudes and motivation, self-efficacy, stress and anxiety, and achievement. Females, especially older females, have tended to assess computers as less effective instructional tools than males, although as access increases, motivation and attitude improve (Krendl \& Broihier, 1992; Liao, 1999; Ogletree \& Williams, 1990). Also, that females have felt less competent using computers is well-documented (Ayerson \& Reed, 1995-96) and may lead to a personalization of a stressful and unsuccessful experience ("If I can't make this work, I must be at fault"). Sherry Turkle (1995) describes this as the "don't touch it, you'll get a shock" factor.

Political factors. Social and political factors in technological environments are interrelated. The issue of access to computers and, by extension, information, is of concern across the world as numerous studies have shown that quality of access has been better for males (Balka \& Doucette, 1994; Gilbert \& Kile, 1996). Shade (1997) continues to identify inequitable access as a major barrier for women's participation on the Internet, and Burge (1994) notes under-representation, marginalization, and inappropriate learning designs for women as barriers to their participation in technology-based learning activities. The nature of 
access has changed over the past several years in the Western world; estimates of access by gender vary substantially and should be evaluated in the light of the context in which they are quoted. For example, although the UN Development Report (Brown \& Jolly, 1999) reported that $38 \%$ of women in the U.S.A. have Internet access, the equality of access may remain different through such factors as more limited time available for access, or older computers and slower connection speeds, which affect the type and amount of information available (Spotts, Bowman, \& Mertz, 1997). Burge identifies the same factors for women faculty attempting to use these technologies for teaching.

Sociological factors. There have been relatively few technological role models for women (Flowers, 1996). Male teachers are more likely to be involved in computing; and a discriminatory environment exists in many classrooms in which technology is a focus (Campbell, 1999). The design of software and language of computing has often reflected a bias towards male culture. Themes typically concern sports, various forms of destruction, and physical adventures. Even course development tools for faculty may reflect androcentric views. For example, the "tool" and "workshop" metaphors used by many productivity tools, while ubiquitous, reflect a male-oriented vocation (e.g. carpentry).

\section{THE FACULTY SURVEY: DIFFERENCES AND TRENDS}

In the first Faculty Survey (1996) a decision to exclude a demographic question about gender of the respondent was a shortcoming. We had the opportunity to remedy that mistake with the second Faculty Technology Survey (1997). The final survey included 48 question categories (some categories contained multiple questions), and 4 demographic questions. It was mailed to 2,041 academic faculty, including full-time sessional staff. The previous Survey was directed only to fulltime tenure-track faculty, and as much of the undergraduate teaching in postsecondary institutions is done by non-tenure track staff, we felt that to include this group would provide a better picture of the response to the use of learning technologies on campus. The return rate was $21 \%$, though a higher response rate would have been desirable. Given the 
length of the survey, its timing (the survey was distributed late in the semester), and the time constraints faced by many academics, getting a higher response rate was a difficult proposition.

As with the first survey, we were unable to determine whether the response rate was determined by a "technology-friendly" or "technoapocalyptic" (Winkelman, 1997) stance. We suspect that respondents were more likely to complete the lengthy survey if they had stronger views about technology, either positive or negative. There is a good chance that those with a more apathetic view towards technology are under-represented in our sample. While self-selection is a concern with lower response rates, since the nature of this paper is more exploratory than confirmatory in nature, response rate is less of an issue.

The results were analyzed for frequencies and cross-tabulated using Pearson's Chi-square to test for structural significance. Any written comments were labeled with gender, Faculty, rank, and age, but all surveys were anonymous. All survey responses were cross-tabulated with gender of respondent and the individual questions, and those yielding significant differences $(p<.05)$ were identified. All of the results reported below are statistically significant at $p<.05$. In addition, only results that showed clear directionality of the results have been included.

In this section, we present data from the Faculty Survey in relation to the main proposition which, restated, suggests that Clark's two components of technology imply that there are two different ways to approach instructional technology:

1. Through the delivery technologies themselves. This has probably been the predominant method to date. Differential effects related to gender probably exist here.

2. Through the instructional methods. Here the tool is chosen to meet an instructional need. This may be the approach favored by female faculty.

We emphasize that the findings presented represent an exploratory, post-hoc analysis of the survey in terms of the questions that relate to the points raised and gender. The survey was not originally designed with these points explicitly in mind, and the data need to be examined in this context. Where significant results are presented, future research 
should be done to confirm these findings and, when possible, try to determine where causal relationships might exist. Nonetheless, the findings have revealed a number of interesting relationships among gender and technology.

\section{Characteristics of Respondents}

The sample was approximately $1 / 3$ female and $2 / 3$ male. However, population is not evenly distributed by gender.

Respondents indicated that $26 \%$ of the female respondents were full professors, compared to $54 \%$ male; $27 \%$ of the women were assistant professors, compared to $13 \%$ of the men; and $22 \%$ of the women were sessional instructors, compared to $11 \%$ of the men. In addition, among Assistant Professors, females tended to be older than their male counterparts $(78 \%$ of females were in the younger median split with $22 \%$ older, compared to males $94 \%$ younger, and $6 \%$ older). Female respondents were more likely to be Instructor/Sessional and Assistant Professors and considerably less likely to be Full Professors. The proportion of Associate Professors was comparable. In addition, on a related item, respondent females were less likely to be at ranks associated with tenure (Table 1). Females were more likely to come from the Faculties of Arts, Education, and Nursing, and less likely to come from Engineering and Science. For other Faculties there were either not clear differences or enough respondents to allow for valid comparisons. On a related item, males were more likely to have had more years teaching experience than females. Finally, while the literature often indicates that females have a higher teaching load than males, no differences were found in the survey data.

The survey listed a number of instructional technologies and asked participants to rate the frequency of use and whether they anticipated increased use in the future. The most frequently used technologies were the traditional "display" technologies of word-processed handouts, transparencies, and chalk or white boards. The most frequently used "modern" technologies were e-mail and distribution lists, course or personal web pages, web-based resources, and computer presentation software. These items also had the highest rating for anticipated increased future 
Table 1

Faculty Rank by Gender

\begin{tabular}{llllll}
\hline & Title & \multicolumn{3}{c}{ V49 Gender } & Total \\
& & & 1 Female & 2 Male & \\
\hline V51 & 1 Instructor/Sessional & Count & 29 & 32 & 61 \\
& & Percent & $21.5 \%$ & $11.1 \%$ & $14.4 \%$ \\
& \multirow{3}{*}{ 2 Assistant Professor } & Count & 36 & 36 & 72 \\
& & Percent & $26.7 \%$ & $12.5 \%$ & $17.0 \%$ \\
& \multirow{3}{*}{3 Associate Professor } & Count & 35 & 66 & 101 \\
& & Percent & $25.9 \%$ & $22.9 \%$ & $23.9 \%$ \\
& 4 4 Full Professor & Count & 35 & 154 & 189 \\
& & Percent & $25.9 \%$ & $53.5 \%$ & $44.7 \%$ \\
Total & & Count & 135 & 288 & 423 \\
& & Percent & $100.0 \%$ & $100.0 \%$ & $100.0 \%$ \\
\hline
\end{tabular}

use. There was a notable increase in use of the WWW and computer presentation software from the previous year's survey.

When asked to assess their skill level on a number of technologies, (a series of questions that paralleled questions that had been asked with the previous survey), there were higher ratings in most of the categories from the previous year. Electronic mail and word processing skills both rated highest, and courseware-authoring packages rated lowest. There were no significant gender-related differences in any of these categories, although female faculty tended to rate their skills lower for courseauthoring tools and production tools such as graphics programs. However, as we will see, female faculty were more inclined to use communications technologies such as e-mail and discussion forums as they supported their instructional decisions, than technologies supporting autonomous work such as computer-assisted instruction. In other words, faculty may be just as inclined to make decisions based on their teaching beliefs and approaches as their skill levels or perceived competencies with specific technologies. 


\section{Gender Differences Related to Technology}

Emphasis on Teaching Role. Three questions were asked that could be used to examine the emphasis of the teaching role based on gender.

Females were more likely to indicate less willingness to maintain existing methods of instruction. When asked to rate the importance of "Maintaining my existing methods of instruction" males were more likely to rate this somewhat important or higher $(65 \%$ male rated it either "important or very important", compared to $53 \%$ female). By contrast, females were more likely to rate this "not at all important or slightly important" ( $48 \%$ female compared to $35 \%$ male).

When asked the frequency with which faculty overhauled their courses, women were more likely to indicate that they have done this more frequently than males. About $94 \%$ of females indicated that they do this at least every 2 or 3 years/times they teach the course compared to $84 \%$ of males.

Females were more likely to indicate that they were very likely to use technology if it expanded what is offered in the course ( $49 \%$ female compared to $33 \%$ male).

One might interpret the results as reflecting a priority placed by females on instruction. To summarize, females were less likely to maintain their existing courses, were more likely to overhaul their classes, and were more likely to use technology if it expanded what could be offered.

Relational Approaches to Teaching. The survey asked several questions related to instructional methodology supported with technology.

Of the different reasons for using technology, females were more likely to agree with the statement "New learning and communications technologies benefit my contacts with students" ( $58 \%$ female compared to $44 \%$ male) and males were more likely to disagree (26\% male compared to $12 \%$ female). Similarly, learning technologies were used to improve student-student interactions: $85.5 \%$ women to $77.5 \%$ men were "likely" or "very likely" to use technology for this purpose. Females were also more likely to indicate "likely" or "very likely" to use instructional technology to bring relevant outside experts into class $(75 \%$ female compared to $50 \%$ male). 
Females were more likely to indicate that they were either "likely" or "very likely" to use technology if it provided a method to better support students' learning styles (63\% female compared to $50 \%$ male). This is consistent with relational approaches to teaching and learning that involve a consideration of the diversity of different learning styles and preferences among learners.

These findings support the major hypothesis that women faculty are more likely to employ learning technologies to both support and extend relational, connected approaches to teaching. In this view, because of their increased emphasis on communication, female faculty may be more likely to use technology as a tool for this purpose. The sharing and communication capacities of the technology were more likely to be seen as relevant. Using instructional methodologies such as $\mathrm{CMC}$, which requires a socially negotiated conversation with others, or integrating Internet resources, may be methods of exposing learners to multiple perspectives, encouraging collaborative learning activities, and fostering interdependence.

Connecting with Colleagues. A number of questions explored the perceived potential of information technologies to create or enhance collegial relationships. The profile of the female faculty member suggests that this would be an important consideration in adopting information technology.

Females were more likely to agree with the statement "New learning and communications technologies have enhanced my contacts with colleagues" ( $68 \%$ female compared to $54 \%$ male). Males were more likely to disagree ( $25 \%$ male compared to $13 \%$ female), suggesting that male faculty are less likely to see technologies in this way.

We were interested in the responses of male faculty to whether technology was a "major factor," "minor factor," or "not a factor" in faculty professional development. Men were more likely to indicate technology as a means to improve faculty than women ( $58 \%$ compared to $44 \%$ ), and females were more likely to indicate this as a minor factor $(46 \%$ female compared to $34 \%$ male). This might indicate that males were more likely to view technology (or the delivery technology) itself as a means for improvement, than females. 
In sum, we believe that women faculty are more inclined to use learning technologies, when they fit with existing instructional goals for the purposes of:

1. increasing contact with their students, and with their colleagues;

2. encouraging interpersonal contact among their students;

3. supporting a view of knowledge as co-constructed with others, and as available from alternative sources;

4. supporting diverse learning styles; and

5. exploring alternative teaching approaches.

\section{CONCLUSION: APPROACHING INSTRUCTIONAL TECHNOLOGY}

We have suggested that women faculty may use different educational and information technologies for different purposes than their male colleagues, and that these differences may relate to three main factors:

- increased emphasis on a teaching role;

- their tendency to explore more relational approaches to teaching;

- their experiences with technologies as female learners and teachers.

If our hypotheses are correct, then female faculty may require or have more benefit from alternative models of support for using technology than males. For example, perhaps technology use should be couched as tools to meet instructional goals, rather than emphasizing the delivery technology alone.

We found differences in the use of technologies for teaching and learning that, in our view, supported Clark's (1994) model of instructional vs. delivery technologies. In general, women tended to prefer to use technology to improve their teaching; increase interaction among learners, themselves, and colleagues; extend the learning opportunities for their students; increase access to alternative sources of expertise, and support different learning needs. Consequently, women seem more likely to consider the instructional methodology side of the technology, compared to males' greater relative earlier emphasis on the delivery 
technology. That is, both groups can come to use instructional technologies but they appear to get there through different routes.

At the least, as revealed by their attitudes, there do seem to be some consistent differences by gender in the Faculty Survey. Among these differences there is support for the hypothesis that women are more likely to spend time on instruction and are more likely to prefer approaches emphasizing communications than males.

This may suggest that there are different approaches to the use of instructional technology. If women are more concerned with the instructional methodology, then the delivery technology itself is secondary and may be considered as a support to instructional methodology. On the other hand, males might more readily consider the delivery technology primary and the instructional methodology secondary. While the role of the instructional methodology is important here too, it is more likely to be considered after the delivery technology is selected. Said another way, males may be more likely to examine the delivery technology first and the instructional methodology second, and women the instructional methodology first and the relevant delivery technology second. If this is true, an increased level of training and support for males, related to instructional methods, may be strategically useful.

Based on this approach, there are some predictions that should be examined in the future. Given some of the problems that historically have influenced women's attitudes about technology, this suggests that there could be a reluctance to use the technology, even when it fits with the instructional methodology of interest. However, should the methods and the appropriate delivery technology clearly fit the instructional goals, a higher likelihood of adoption might be expected, since the delivery and the methodology are aligned.

We hypothesized that females who choose to use instructional technology are more likely to do so to help facilitate their instructional methodology's objectives. For example, if the instructor wants to build a community through a discussion environment (instructional methodology), he/she will be more likely to have a predisposition towards computer mediated conferencing (the delivery technology that supports online discussion) or other tools that facilitate this instructional goal. 
The Faculty Survey revealed gender-related differences in perceptions and use of educational technologies among male and female faculty at the University of Alberta. The Survey is only the first step in exploring these differences on our campus and in developing environments that will support instructional technology for both faculty and learners. These environments could be nurtured using both adult learning theory and feminist research. In the immediate future, the interpretation of the Survey data has encouraged us to reconsider programming for faculty development and support. For example, women faculty may prefer pedagogically based training where relevant tools are presented. Males may prefer training featuring a delivery technology where instructional methods are also addressed.

While helpful for identifying trends, the Survey methodology does not allow for a rich examination of the data, especially in understanding reasons behind the responses. To better understand female personal experiences with technology, the first author is currently conducting a multi-dimensional longer-term study on the interaction of gender issues with technology. This study currently involves over four dozen female faculty members from every Faculty at our University, in a project of "pedagogical activism," or participatory/emancipatory action research (McTaggart, 1997) with the ultimate goal being the transformation of practice. Sharing stories of practice, the participants will eventually support Winkelman's (1997) idea of an electronic hermeneutic in which accounts of experience are made available for re-telling in an online collaborative community. A growing and connected community of practice may lead to alternative models of instructional support and more critical and profound instructional practice with technology, a practice Winkelman describes as liberating, rather than alienating for teachers and learners. A more recent survey of faculty, sessionals, and graduate teaching assistants is currently being analyzed and should allow a better examination of some of these questions in a teaching and learning context. 


\section{Notes}

1 The survey data are available online at http://www.atl.ualberta.ca/articles/evaluation/summary_1997_faculty_survey_es.htm

2 That learning and knowing may be socially constructed has been challenged from within feminist circles, as well as from more traditionally rooted, rational paradigms (Ganguly, 1992; Patai \& Koertge, 1994).

\section{References}

Aisenberg, N., \& Harrington, M. (1988). Women of academe: Outsiders in the sacred grove. Amherst, MA: University of Massachusetts Press.

Anderson, T., Varnhagen, S., \& Campbell, K. (1998). Faculty adoption of teaching and learning technologies: Contrasting earlier adopters and mainstream faculty. Canadian Journal of Higher Education, 28(2/3), 71-98.

Ayerson, D.J., \& Reed, W.M. (1995-96). Effects of learning styles, programming, and gender on computer anxiety. Journal of Research on Computing in Education, 28(2), 148-161.

Balka, E., \& Doucette, L. (1994). The accessibility of computers to organizations serving women in the province of Newfoundland: Preliminary Study Results (1). The Arachnet Electronic Journal on Virtual Culture, 2(3), 1-27.

Bromley, H. (1998). Introduction: Data-driven democracy? Social assessment of educational computing. In H. Bromley, \& M.W. Apple (Eds.), Education, technology and power: Educational computing as social practice (pp. 1-28). Albany, NY: SUNY Press.

Bryson, M., \& de Castell, S. (1998). Telling tales out of school: Modernist, critical, and postmodern "true stories" about educational computing. In H. Bromley, \& M.W. Apple (Eds.), Education, technology and power: Educational computing as social practice (pp. 65-84). Albany, NY: SUNY Press.

Burge, E.J. (1994). Learning in computer conferenced contexts: The learners' perspective. Journal of Distance Education, 9(1), 19-43.

Campbell, K. (1999) Designs for computer-based learning: Designing for inclusivity. Technology and Society: Gender and Computer Technologies. (A special issue of IEEE), 18(4), 28-34.

Clark, R.E. (1994). Media will never influence learning. Educational Technology Research and Development, 42(2), 21-29. 
Clegg, S., Mayfield, W., \& Trayhurn, D. (1999). Disciplinary discourses: A case study of gender in information technology and design courses. Gender and Education, 11(1), 43-55.

Cockburn, C, \& Ormrod, S. (1993). Gender and technology in the making. London: Sage Publications.

Cumming Speirs, C., Amsel, R., Baines, M.G., \& Pickel, J. (1998). Off the track: A profile of nom-tenure track faculty at McGill University. The Canadian Journal of Higher Education, 28(2/3), 1-20.

Dagg, A.I. (1998). Hiring women at Canadian Universities: The subversion of equity. In J. Stalker \& S. Prentice (Eds.), The illusion of inclusion: Women in postsecondary education (pp. 108-118). Halifax, NS: Fernwood Publishing.

Elijah, R. (1996). Professional lives; institutional contexts: Coherence and contradictions. Teacher Education Quarterly, 23(3), 69-90.

Elliott, A.E., \& Woloshyn, V.E. (1997). Some female professors' experiences of collaboration: Mapping the collaborative process through rough terrain. The Alberta Journal of Educational Research, 43(1), 23-36.

Ewing, J.M., Dowling, J.D., \& Coutts, N. (1998). Learning using the World Wide Web: A collaborative learning event. Journal of Educational Multimedia and Hypermedia 8(1), 3-22.

Flowers, J.C. (1996). Female educators and students assess gender equity in technology education: A survey of women involved in technology education. (Virginia State Department of Education). Commonwealth of Virginia.

Ganguly, K. (1992). Accounting for others: feminism and representation. In L.F. Rakow (Ed.), Women making meaning: New feminist directions in communication (pp. 60-79). New York, NY: Routledge.

Gates, G.S. (2000). Teaching-related stress: The emotional management of faculty. The Review of Higher Education, 23(4), 469-490.

Gilbert, L., \& Kile, C. (1996). Surfer grrrls. Seattle, WA: Seal Press.

Gillespie, F. (1998). Instructional design for the new technologies. New Directions for Teaching and Learning, 76, 30-52.

Hagedorn, L.S. (1996). Wage equity and female job satisfaction: The role of wage differentials in a job satisfaction causal model. Research in Higher Education, 37(5), 569-598.

Hamrick, F. (1998). "I Have Work to Do": Affirmation and marginalization of women full professors. Paper presented at the annual meeting of the American Educational Research Association, April 1998, San Diego. 
Hara, N., \& Kling, R. (2000). Students' distress with a Web-based distance education course: An ethnographic study of participants' experiences. Retrieved from the World Wide Web November 6, 2001 at $\mathrm{http} / / / \mathrm{www}$. slis.indiana.edu/CSI/papers.html

Hornig, L.S. (1980). Untenured and untenuous: The status of women faculty. Annals of the American Academy of Political and Social Science, 448, 115-125.

Inkpen, K. (1997). Three important research agendas for educational multimedia: Learning, children, and gender. Proceedings of Educational Multimedia '97, June 1997, Calgary, AB.

Kimmel, E. (1999). Feminist teaching, an emergent practice. In S.N. Davis, M. Crawford, \& J. Sebrechts (Eds.), Coming into her own (pp. 57-76). San Francisco, CA: Jossey-Bass.

Krendl, K., \& Broihier, M. (1992). Student responses to computers: A longitudinal study. Educational Computing Research, 8(2), 215-228.

Kulis, S. (1997). Gender segregation among college and university employees. Sociology of Education, 70(2), 151-173.

Lacey, C.H., Saleh, A., \& Gorman, R. (1998). Teaching nine to five: A study of the teaching styles of male and female professors. Paper presented at the annual meeting of the Women in Educational Leadership Conference, October 1998, Lincoln, NE.

Liao, Yuen-kuang (1999). Gender differences on attitudes towards computers: A meta-analysis. Paper presented at the annual meeting of the World Conference on Educational Multimedia, Hypermedia and Telecommunications, June 1999, Seattle, WA.

MacKeracher, D. (1996). Making sense of adult learning. Toronto, ON: Culture Concepts, Inc.

Magolda, M.B.B. (1992). Knowledge and reasoning in college: Genderrelated patterns in students' intellectual development. San Francisco, CA: Jossey-Bass Publishers.

McTaggart, R (Ed.) (1997). Participatory action research: International contexts and consequences. New York, NY: State University of New York Press.

Middleton, S (1993). Educating feminists: Life histories and pedagogy. New York, NY: Teachers College Press.

Morrison, J.L. (1997). The technology: One professor's odyssey. The Technology Source. Retrieved November 6, 2001 on the World Wide Web at http://ts.mivu.org/default.asp?show=article \&id=537 
Nawratil, G. (1999). Implications of computer-conferenced learning for feminist pedagogy and women's studies: A review of the literature. Resources for Feminist Research, 27(1/2), 73-107.

Ogletree, S.M., \& Williams, S.W. (1990). Sex and sex-typing effects on computer attitudes and aptitude. Sex Roles, 23(11/12), 703-712.

Park, S.M. (1996). Research, teaching, and service: Why shouldn't women's work count? The Journal of Higher Education, 67(1), 46-84.

Pryor, J. (1995). Gender issues in groupwork: A case study involving work with computers. British Educational Research Journal, 21(3), 277-287.

Quazi, S. (1996). Faculty renewal in Canada and Ontario: No forthcoming shortage! (With particular reference to education professors). Interchange, 27(2), 173-197.

Ramsden, P., \& Martin, E. (1996). Recognition of good university teaching: Policies from an Australian study. Studies in Higher Education, 21(3), 299-305.

Robin, B.R., \& Harris, J.B. (1998). Correlates among computer-using teacher educators' beliefs, teaching and learning preferences, and demographics. Journal of Educational Computing Research, 18(1), 15-35.

Rogers, E. (1995a). Diffusion of innovations (4th ed.). New York, NY: The Free Press.

Russell, T.L. (1997). The no significant difference phenomena as represented in 248 research reports, summaries, and papers. Raleigh, NC: University of North Carolina Press.

Shade, L.R. (1993). Gender issues in computer networking. Paper presented at Community Networking: the International Free-Net Conference, Carleton University, August 1993, Ottawa, ON.

Shade, L.R. (1997). Preliminary actions towards achieving gender equity. Paper presented at the International Council of Women, June 1997, Ottawa, ON.

Singer, E.R. (1996). Espoused teaching paradigms of college faculty. Research in Higher Education, 37, 659-679.

Spender, D. (1995). Nattering on the Net: Women, power, and cyberspace. Australia: Spnifex Press.

Spenneman, D.H.R. (1996). Gender imbalances in computer access among environmental science students. Journal of Instructional Science and Technology, I(2).

Spotts, T.H., Bowman, M.A., \& Mertz, C. (1997). Gender and use of instructional technologies: A study of university faculty. Higher Education 34, 421-436. 
Stecklein, J.E., \& Lorenz, G.E. (1986). Academic women: Twenty-four years of progress? Liberal Education 72(1): 63-71.

Suchman, \& Jordan, B. (1988). Computerization and women's knowledge. In Women, work, and computerization: IFIP conference proceedings, Amsterdam.

Taylor, J. (1997). Warming a chilly classroom. ASEE Prism, February, 29-33.

Taylor, H.G., \& Mounfield, L.C. (1994). Exploration of the relationship between prior computing experience and gender on success in college computer science. Journal of Educational Computing Research, 11(4), 291-306.

Tisdell, E.J. (2000). Feminist pedagogies. In E. Hayes \& D.D. Flannery (Eds.), Women as learners: The significance of gender in adult learning (pp. 155-183). San Francisco, CA: Jossey-Bass.

Turkle, S. (1995). Life on the screen: Identity in the age of the internet. New York, NY: Simon \& Schuster.

Valian, V. (1998). Women in academia. In Why so slow? The advancement of women (pp. 217-249). Cambridge, MA: The Massachusetts Institute of Technology Press.

Verrier, D.A. (1994). Perceptions of life on the tenure track. Thought and Action, 9(2), 95-124.

Weiler, K (1988). Women teaching for change: Gender, class, and power. New York, NY: Bergin and Garvey.

Weiler, K. (1998). Freire and a feminist pedagogy of difference. In C.A. Woyshner \& H.S. Gelfond (Eds.), Minding women: Reshaping the educational realm (pp. 117-145). Cambridge, MA: Harvard Educational Review.

Wenneras, C., \& Wold, A. (2000). .Millennium essay: A chair of one's own. Nature, December (408), 647.

Winkelman, C. (1997). Women in the integrated circuit: Morphing the academic/community divide. Frontiers: A Journal of Women Studies, 18(1), 19-42.

Wylie, M. (1995). No place for women: Internet is a flawed model for the Infobahn. Digital Media, 4(8), 3. 